\title{
Course of ice phenomena in small water reservoir in Katowice (Poland) in the winter
}

\author{
season $2011 / 2012$
}

\author{
Robert Machowski
}

Department of Physical Geography, Faculty of Earth Sciences, University of Silesia, Będzińska Str. 60, 41-200 Sosnowiec, Poland E-mail address: robert.machowski@us.edu.pl

\begin{abstract}
Investigations on the ice phenomena were carried out on a small water reservoir located in the northern part of Katowice, at A4 motorway, in terrains of the Shopping-Service Centre "3 Ponds" ("Trzy Stawy"). Observations on the course of ice phenomena were performed in the winter season 2011/2012. Measurements were started in the moment occurrence of the first forms of the ice phenomena and were finished after their complete disappearance. The investigations had a character of systematic, daily observations and consisted in the mapping of ice phenomena. Among basic research aims should be numbered as follows: evaluation of the ice phenomena course, the identification of the ice phenomena forms, determination of changes in the range of ice cover and its characteristics in terms of recreational use as well. The first effects of low air temperatures occurred on the $19^{\text {th }}$ November of 2011. At the beginning the ice phenomena in a form of so-called shore naledi and shore ice appeared. The formation of a compact ice cover happened not before than after nearly two months. Permanent ice cover formed on $16^{\text {th }}$ January 2012. At the end of ice cover occurrence its crashing followed, reflecting in a form of numerous fissures in the ice. The complete disappearance of processes and forms ice phenomena happened on the $21^{\text {st }}$ March 2012. Ice phenomena in the winter season $2011 / 2012$ occurred for 124 days from the $18^{\text {th }}$ November 2011 till the $21^{\text {st }}$ March 2012, including uninterruptedly for 65 days. Ice cover in the initial stage had an ephemeral character. Safe recreational use of ice cover at the reservoir (e.g. walking, fishing, ice skating) was possible only for about 20 days, when its thickness exceeded $15 \mathrm{~cm}$ and ice composition had a homogenous (crystalline) structure. The course of ice phenomena indicates their quasinatural character, resulting from the natural conditions.
\end{abstract}

KEY WORDS: ice cover, cryology, limnology, urban area

\section{Introduction}

In the last years the intensification of investigations on the ice phenomena on lakes and especially within anthropogenic water reservoirs is observed. As SOLARSKI \& PRADELA (2011) give the studies including results of investigations carried out in a larger time perspective predominate. The beginning and disappearance of ice phenomena, duration of ice cover occurrence and its thickness as well are usually taken into account. On the base of this information and average values of air temperature are drawn conclusions on the historical and present-day climate changes (e.g. LENORMAND ET AL., 2002; MARSZELEWSKI \& SKOWRON, 2005, 2006, 2009; CHOIŃSKI ET AL., 2009, 2013). Slightly different kind is typical of short-term investigations, which are usually performed during one or two winter seasons. They have a more detailed character. In this type of considerations the influence of air temperature on the course of ice phenomena and anthropogenic influences modifying the natural processes as well are most often analysed (e.g. GRZEŚ, 1974; PASŁAWSKI, 1982; JANKOWSKI ET AL., 2009; SOLARSKI \& PRADELA, 2010; RzĘTAŁA, 2012). Their intensity is especially observed within anthropogenic water reservoirs located in strongly urbanised and industrialised terrains. Investigation works carried out have usually cognitive and utility values in relation to safe use of frozen over water surface (e.g. MACHOWSKI \& RUMAN, 2009; RZĘTAŁA \& RZĘTAŁA, 2009; SOLARSKI ET AL., 2011).

Previously the observation on ice phenomena at artificial water reservoirs in this part of Poland 
were carried out unusually rarely or they made the part of investigations of wider spectrum (e.g. JAGUŚ \& RZĘTAŁA, 2003, 2008; RZĘTAŁA, 2003, 2008). Hitherto existing unsatisfactory knowledge of ice phenomena of water reservoirs in the terrain described was also noticed by CHOIŃSKI (2007) in the textbook entitled "Physical limnology of Poland". According to JANKOWSKI ET AL. (2009) it is the consequence of water reservoirs functioning under quasi-natural conditions, and subject to extremely strong human impact as well, what effect is a large complexity of ice phenomena course. As BAJKIEWICZ-GRABOWSKA ET AL. (1993) give among forms of standing water ice phenomena are numbered shore ice, permanent ice cover and ice float, and ice phenomena are most often defined as the presence of ice in the surface layer reservoir regardless of its structure, form and duration of occurrence (CHOIŃSKI, 2007). Changes in the course of ice phenomena under natural conditions are most of all shaped by meteorological and climatic conditions typical of the given place and the heat exchange between water mass and near-surface atmosphere layer (BAJKIEWICZGRABOWSKA ET AL., 1993). In the area described these dependencies are additionally modified by the whole of conditions of anthropogenic origin (RZĘTAŁA, 2008).

\section{Study area}

Investigations on the icing were carried out within small water reservoir located in the northern part of Katowice, at A4 highway, in terrains of the Shopping-Service Center „3 Ponds” ("Trzy Stawy”)
(Fig. 1). The analysed reservoir is rather small, its area reaches not quite 1 ha. It is $185 \mathrm{~m}$ long, $71 \mathrm{~m}$ wide and the length of shoreline amounts to $431 \mathrm{~m}$. This reservoir in main measure is fed with atmospheric precipitation and shallowly occurring underground waters. In its western part at the bottom the outlet of draining pipe occurs, which drains the waters originating from drainage of previous water logged area (now it is built-up). This reservoir and its neighbourhood has a notably anthropogenic character. In connection with building of the shopping centre its range was significantly limited. Shores were fixed by stony pavement, and then covered by earth material and sown with grass. The direct neighbourhood of reservoir is made of asphalted surfaces of parking spaces, access roads of D class and motorway (Fig. 1).

The described reservoir (Fig. 2) is located in the middle part of Katowice Upland, one of five mesoregions of the Silesian Upland (KONDRACKI, 2002). Considering geomorphology these terrains are numbered among the Bytom-Katowice Plateau (separated by GILEWSKA, 1972), which lies in the southern part of the Silesian Upland, where horst character of the relief predominates. In the deep substratum making the basement of the Katowice Upland the Devonian-Carboniferous deposits are located (SоKоŁOWSKI, 1990). Formations of the Carboniferous age are covered by the Permian deposits with vulcanites, and the Triassic deposits and rocks from the Tertiary as well (KOTAS, 1982). The Quaternary deposits of varied thickness occur directly at the terrain surface (KARAś-BRZOZOWSKA, 1960).

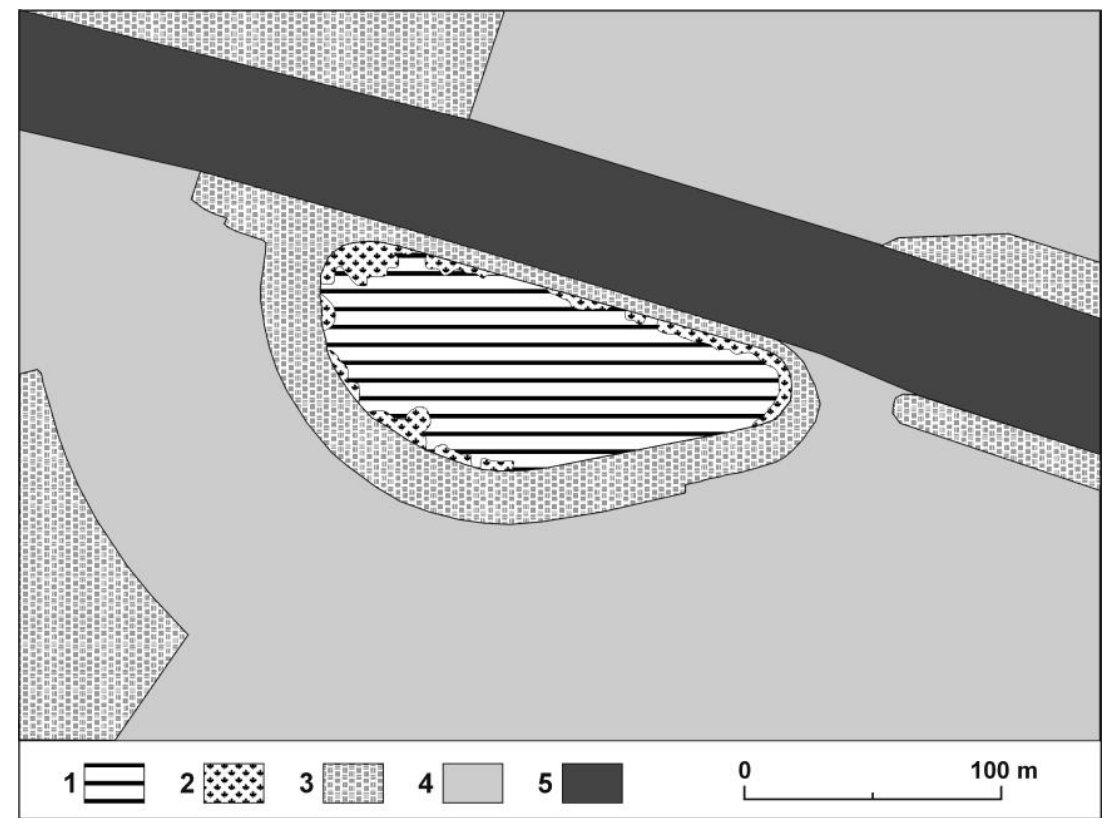

Fig. 1. Neighbourhood of the investigated water reservoir

1 - water reservoir; 2 - rush vegetation; 3 - sodded terrains; 4 - service terrains and access roads of D class; 5 - motorway 


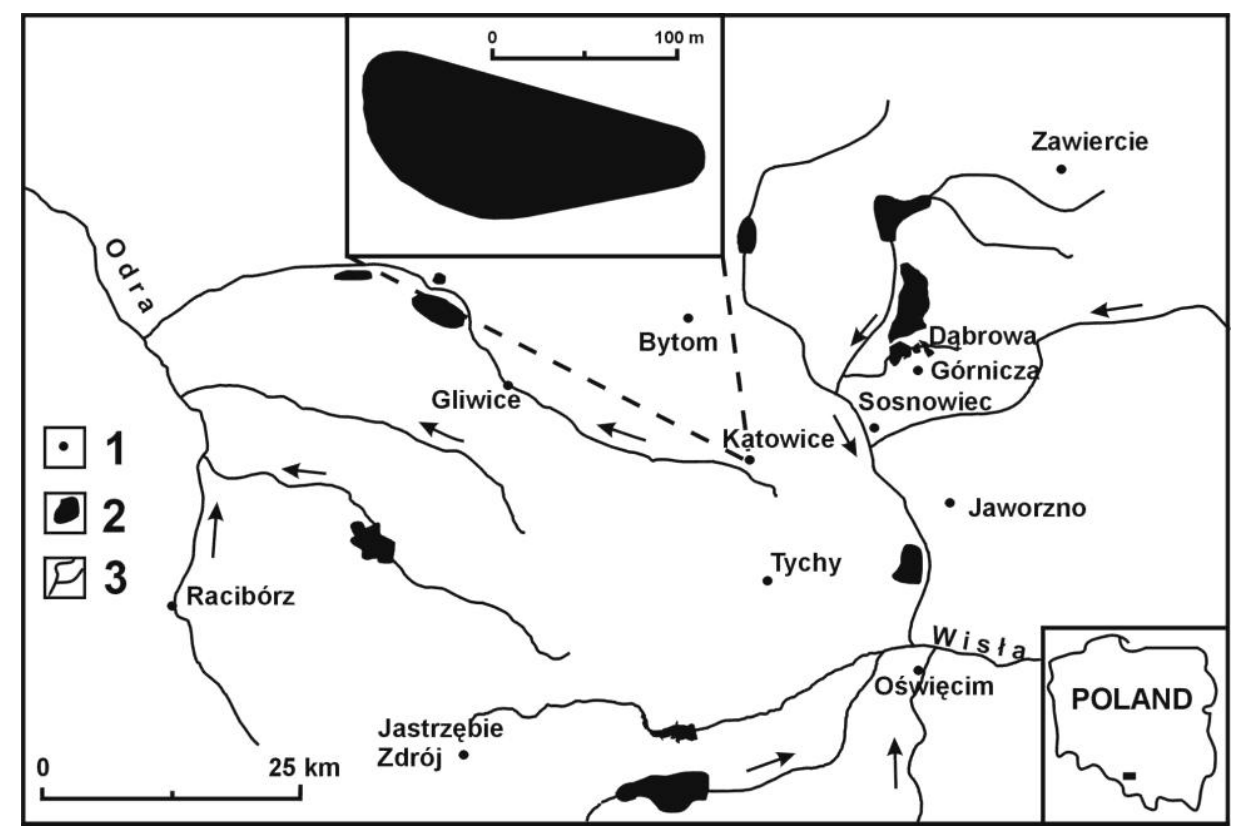

Fig. 2. Location of the investigated water reservoir in the Silesian Upland 1 - selected cities; 2 - larger water reservoirs; 3 - water network

The Katowice Upland is characterised by changes in the natural environment caused by the economic human activity. The predominating role played here industrialisation (significant concentration of many branches of industry and mining) and connected with it the development of urbanization as well. Widely understood the human impact included all elements of the natural environment. In result of it in the described area many artificial landforms of different kind appeared. Among them it is possible to observe depressions and convex landforms, which to a significant degree contributed to the smoothing over the natural features of this terrain relief. In many new terrain depressions water reservoirs linger (ŻMUDA, 1973; WACH, 1991; SZCZYPEK, 1995; PEŁKA-GOŚCINIAK, 2006; and others).

\section{Material and methods}

Observations on the course of ice phenomena in the described water reservoir were carried out in the winter season 2011/2012. Measurements were started at the moment of appearance of the first forms of ice phenomena and were finished after their complete disappearance, in the period from 18.11.2011 till 21.03.2012. Investigations had a character of systematic, daily observations. Investigations consisted in the mapping of ice phenomena. In the course of every single measurement series the visual evaluation of the ice phenomena course was made considering forms of occurring ice and its structure. The occurrence of ice cover and the appearing of water on the ice was also taken into account. The special pressure was brought on the identification of water freezing conditions in the initial stage of ice cover appearance and ice melting in the period of its disappearance, and the whole of these observations was completed with measurements of ice thickness. The ice structure and thickness were determined on the base of drillings made in the ice with using of ice auger and by using a specially constructed so-called scythe to ice (scoop). In periods, when ice did not secure safe moving on it, measurements were made at freshly made fracture in thicker sheet. The proper evaluation of the course of ice phenomena in the described water reservoir and the interpretation of obtained results was also possible on the base of meteorological data obtained from the climatologic station of the Institute of Meteorology and Water Management in Katowice. Considering a small size of water reservoir the minimum temperature at the ground was taken into account in the study. This coefficient betokens the occurrence of ground frost, what is of large importance for the appearance of the first forms of ice phenomena: shore naledi and ice. The completion of the whole of investigations was also made by the photographic documentation.

Among basic cryologic aims of reservoir investigations one should number as follows: evaluation of ice phenomena course of small water reservoir, identification of ice phenomena forms, determination of changes in ice cover range, and characteristics of ice cover in the usable aspect as well. The lack of thermal pollutants, limited supply of mineral and organic pollutants 
allowed formulating a hypothesis of similar course of ice phenomena and large analogy to natural reservoirs in this respect.

\section{Results}

The first effects of low air temperatures in cooled masses of stored waters within reservoir described occurred on 19th November of 2011. (Fig. 3). At the beginning ice phenomena occurred in the form of so-called ice naledi and shore ice, which were observed especially in western and eastern sectors of the reservoir (Fig. 4). Dynamical changes in the air temperature caused the periodical appearance of a compact ice cover of $1 \mathrm{~cm}$ thick on the whole reservoir that in the afternoon hours completely disappeared. Such a situation remained till the $24^{\text {th }}$ November. The following several days were again a period, when in the reservoir only shore ice was observed. It appeared in other places and its area was varied (Fig. 5). In the period from the $20^{\text {th }}$ till the $27^{\text {th }}$ December of 2011 in the reservoir the compact ice cover of maximum thickness of $4 \mathrm{~cm}$ remained (23 ${ }^{\text {th }}$ December), which underwent destruction on the 28th December. After this time happened a period without ice phenomena lasting for the following 19 days till the $15^{\text {th }}$ January of 2012 inclusive (Fig. 3).

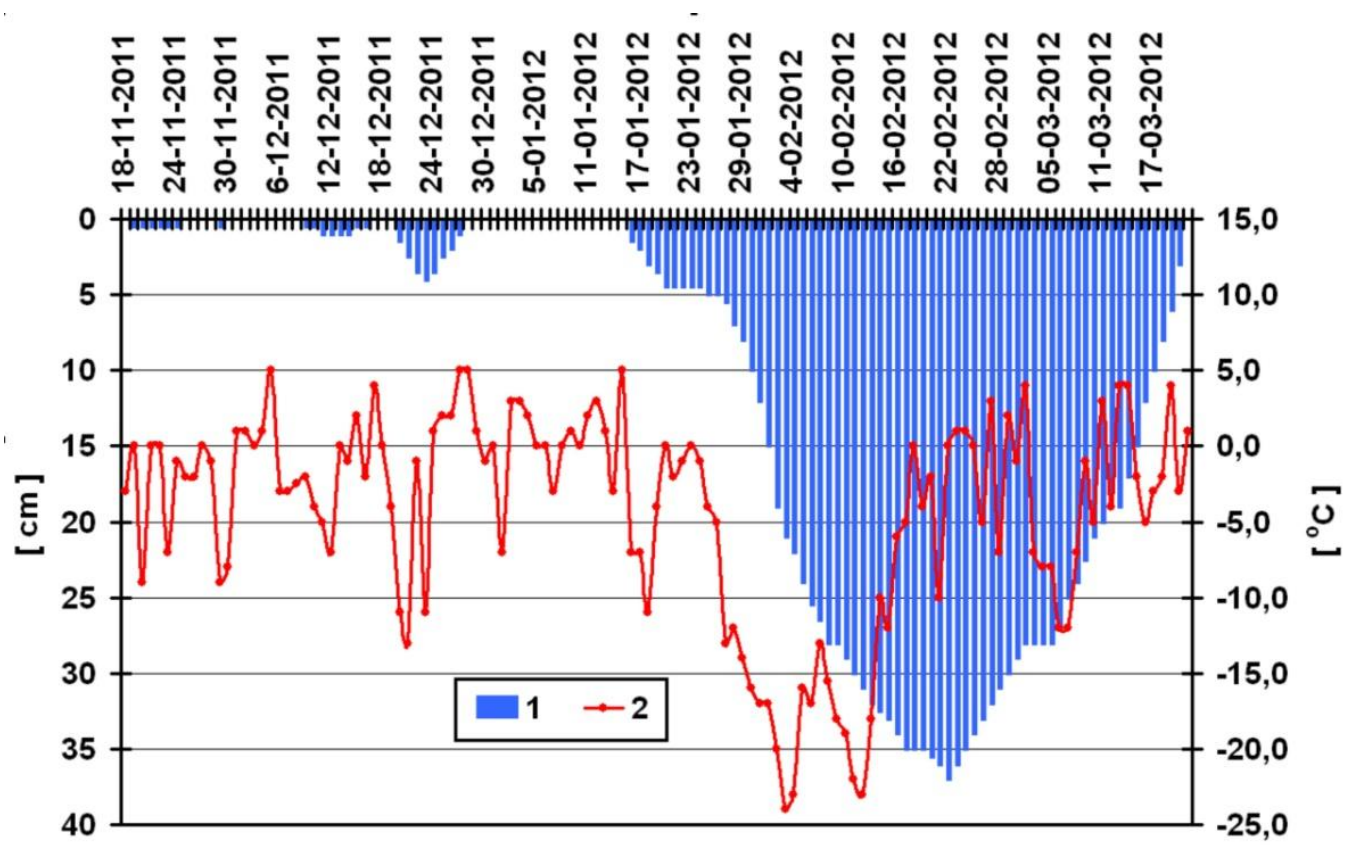

Fig. 3. Changes in the thickness of ice cover in the winter season 2011/2012 against the background of minimum air temperature at the ground

1 - thickness of compact ice cover; 2 - minimum temperature at the ground

Another period of occurrence of ice phenomena in the water reservoir consisting in the formation of compact ice cover happened not before than 2 months since the appearance of the first signs of ice phenomena. Permanent ice cover on the described water reservoir was started on the $16^{\text {th }}$ January of 2012 year. On this day after the distinct night coolness the compact ice cover of the thickness of $1.5 \mathrm{~cm}$ appeared (Fig. 3). The following days were characterized by a small, but a systematic increase in the ice thickness, on the $20^{\text {th }}$ January its thickness reached $4.5 \mathrm{~cm}$. The compact ice cover of such thickness remaining within the reservoir for the following 4 days, and afterwards a small its increase occurred again. Not before than at the end of January and at the beginning of February, together with the large temperature decrease below $0^{\circ} \mathrm{C}$ the distinct increase in the ice thickness exceeding $20 \mathrm{~cm}$ (Fig. 3) occurred. Lasting low temperatures caused the further, rather fast ice increase. At the beginning of the second decade of February the maximum ice thickness was stated, which amounted to $37 \mathrm{~cm}$.

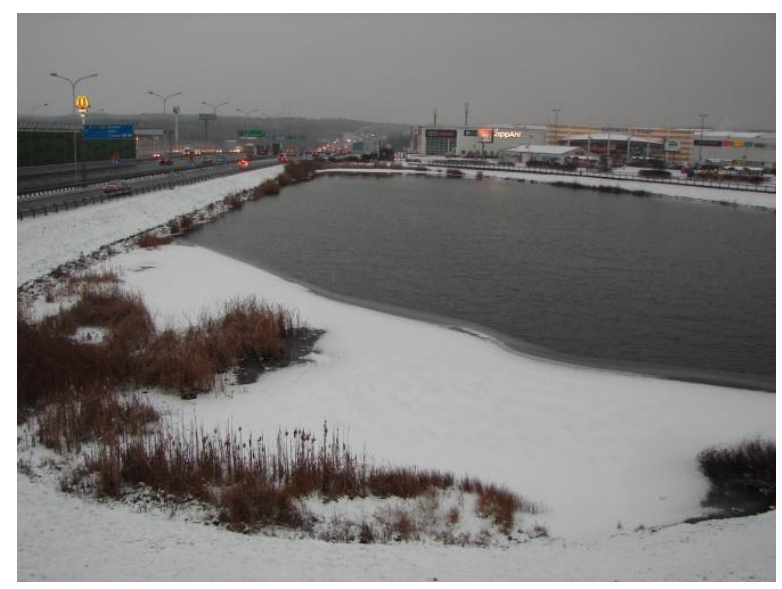

Fig. 4. Partial ice cover within reservoir in the period of its freezing (R. Machowski) 


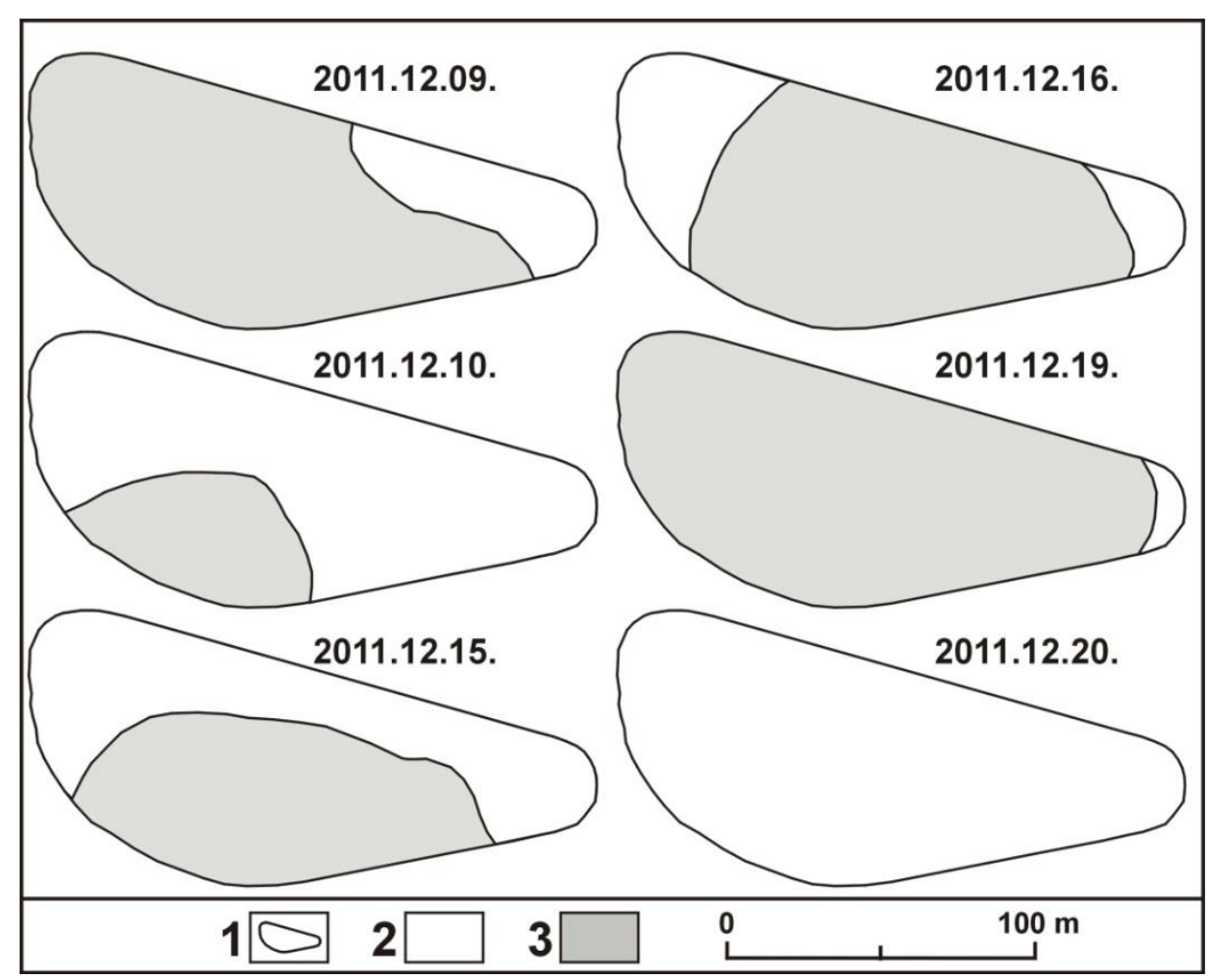

Fig. 5. Stages of water reservoir freezing

1 - shoreline of reservoir; 2 - surface of water region with ice cover; 3 - surface of water region free of ice cover

The last period of ice phenomenon occurrence is characterised by a slow and systematic decrease in ice thickness, which caused its complete disappearance. The destruction of ice cover started together with the occurrence of positive temperatures at the end of February and at the beginning of March. The velocity of its disappearance had a varied course in the particular sectors of the reservoir. At the earliest the effects of thaw happened in the shore zone, where in places the ice completely disappeared. At the same time on the ice cover large amount of melting waters appeared, intensifying decrements in the ice mass. During the aerial liquidation of ice cover, which lasted about three weeks, short episodes of water freezing and reconstruction of ice cover in the shore zone occurred. This period was also characterized by the change in the ice structure from crystalline into the granular. At the end of ice cover occurring its crashing was observed, reflecting in a form of numerous fissures in the ice. The complete disappearance of ice phenomena processes and forms occurred on the $21^{\text {st }}$ March of 2012 year (Fig. 3).

The duration of ice phenomena at the described reservoir amounted to 124 days, and considering the days without any form of ice, which occurred after the first signs of ice phenomena, this period undergoes shortening of 35 days. It is connected with several-days-long cycles of warming up in the first phase occurrence of ice phenomena in the water reservoir.

\section{Discussion}

At the beginning appeared ice phenomena in the form of so-called shore naledi, which are typical of the majority of water reservoirs in the first phase of freezing (RZĘTAŁA \& RZĘTAEA, 2009; MACHOWSKI \& RZĘTAŁA, 2010) and shore ice, which occurred in different range in the sectors of the reservoir (Fig. 4). Shore naledi and generally weakly shaped shore ice, are usually only forms of ice phenomena in the case of reservoirs occurring in the Silesian Upland, which are loaded with thermal pollutants (RZĘTAŁA ET AL., 2009; SOLARSKI ET AL., 2011).

The first period of the occurrence of a compact ice cover occurred in the second half of December. At similar reservoirs the compact ice cover appeared already in the third decade of November at the earliest. Reservoirs of hundreds ha in area are completely ice covered not before than in the third decade of December, and these, which store polluted waters even in the third decade of January (SOLARSKI ET AL., 2010). Sometimes is also observed a certain deviation from this rule conditioned by weather anomalies, whereas even relatively small reservoirs of pure waters completely freeze not before the end of December or at the beginning of 
January (MACHOWSKI \& RUMAN, 2009; SOLARSKI \& PRADELA, 2010). Situation of such type also refers to the described reservoir, because the permanent and the compact ice cover appeared only in the mid-January. The compact ice cover of changing thickness is especially dangerous during recreational using of frozen water reservoirs. Because its location the described reservoir is quite often visited by population, therefore for warning purposes at its shores the proper signs were set that forbid among others the winter use of frozen ice cover (Fig. 6). Among the various forms of recreational use of the ice on the described reservoir was observed only fishing, ice skating and walks on the frozen surface of the ice.

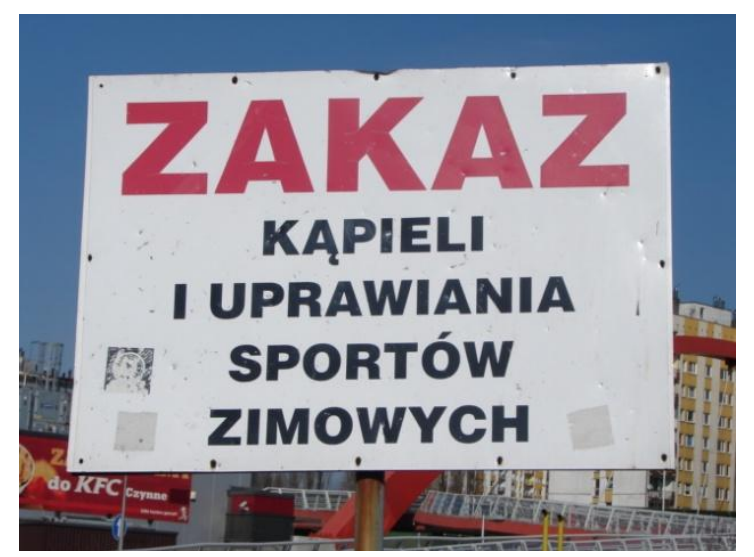

Fig. 6. Warning sign forbidding recreational use of the reservoir in the winter period (R.Machowski)

The maximum thickness of ice cover shaped within the investigated reservoir is slightly larger than the average, which amounts to $31 \mathrm{~cm}$ and was calculated by RZETAŁA ET AL., (2009) on the base of investigations carried out in 2006 in more than 50 water reservoirs. Decidedly smaller ice thickness originated in water reservoirs located in Gliwice, where in 2011 the maximum thickness of compact ice cover was stated at the level from $18.5 \mathrm{~cm}$ within the Stanisław reservoir up to $21.5 \mathrm{~cm}$ in Cegielnia reservoir. The comparable values were obtained in a case of small water reservoir in Czeladź (RZĘTAŁA \& SOLARSKI, 2011; RZĘTAŁA, 2012) and within small water reservoirs located in the strongly urbanized area of Ruda Śląska $(23 \mathrm{~cm})$ as well. Larger ice thickness at the level of about $40 \mathrm{~cm}$, was stated in 2006 year within the Pogoria III reservoir in Dąbrowa Górnicza.

Destruction of ice cover happened together with the occurrence of the first positive temperatures at the end of February and at the beginning of March. This process was started by a few dozen centimetres thawing at the edge of ice cover at the shore. Analogous situation is typical of many other water reservoirs, functioning in this region, independently on their size (RzETAŁA ET AL., 2009; SOLARSKI ET AL., 2011). The spring warming up weakens the ice structure at the whole surface of the reservoir, causing cracking and wind translocation of disintegrated ice layer, what accelerates its disappearance. The period of the latest disappearance of ice cover falls on the second decade of April, such a long ice occurrence was stated at the Kozłowa Góra water reservoir, which is situated in the northern part of the Silesian Upland (JAGUŚ \& RZĘTAŁA, 2003).

\section{Conclusions}

The investigations on the occurrence of ice cover carried out in the winter season 2011/2012 within a small water reservoir located in Katowice allow presenting some conclusions:

(1) Ice phenomena in the winter season $2011 / 2012$ occurred for 124 days from the $18^{\text {th }}$ November 2011 till 21st March 2012, including uninterruptedly for 65 days.

(2) The compact ice cover happened two times. The ice cover in the initial period had an ephemeral character. The complete freezing began on the $16^{\text {th }}$ January of 2012.

(3) Safe recreational use of ice cover of water reservoir was possible only for about 20 days, when its thickness exceeded $15 \mathrm{~cm}$ and ice composition had a homogenous (crystalline) structure.

(4) The course of ice phenomena indicates their quasi-natural character, resulting from the natural conditions.

\section{References}

Bajkiewicz-Grabowska E., Magnuszewski A., Mikulski Z. 1993. Hydrometria. Wyd. Nauk. PWN, Warszawa.

Choiński A. 2007. Limnologia fizyczna Polski. Wyd. Nauk. UAM, Poznań.

Choiński A., Kolendowicz L., Pociask-Karteczka J. 2009. Zjawiska lodowe na Morskim Oku jako wskaźnik zmian klimatu w Tatrach. [in:] Jankowski A.T., Absalon D., Machowski R., Ruman M. (eds.) Przeobrażenia stosunków wodnych $w$ warunkach zmieniającego się środowiska. Uniw. Śl., WNoZ, Pol. Tow. Geogr., Oddz. Katowicki, Regionalny Zarząd Gosp. Wod. w Gliwicach, Sosnowiec: 71-77.

Choinski A., Ptak M., Strzelczak A. 2013. Areal variation in ice cover thickness on lake Morskie Oko (Tatra Mountains). Carpathian J. of Earth and Environ. Sc., 8 (3): 97-102.

Gilewska S., 1972. Wyżyny Śląsko - Małopolskie. [in:] Klimaszewski M. (ed.) Geomorfologia Polski. T. 1. Polska południowa. Góry i wyżyny. PWN, Warszawa: 232-339.

Grześ M. 1974. Badania nad termikq i zlodzeniem jeziora Gopło. Dokum. Geogr., z. 3, Inst. Geogr. PAN, Warszawa.

Jaguś A., Rzętała M. 2003. Zbiornik Kozłowa Góra. Funkcjonowanie i ochrona na tle charakterystyki geograficznej i limnologicznej. Pol. Tow. Geogr., Kom. Hydrol., Warszawa.

Jaguś A., Rzętała M. 2008. Znaczenie zbiorników wodnych $w$ kształtowaniu krajobrazu (na przykładzie kaskady jezior 
Pogorii). Akad. Techn.-Hum., WNoMiŚ, Uniw. Śląski, WNoZ, Bielsko-Biała - Sosnowiec.

Jankowski A.T., Machowski R., Piątek M., Ruman M., Rzętała M., Rzętała M.A., Solarski M. 2009. Cechy charakterystyczne zlodzenia zbiorników wodnych w regionie górnośląskim. [in:] Marszelewski W. (ed.) Anthropogenic and natural transformations of lakes. Vol. 3. Pol. Limnol. Soc., Torun: 103-108.

Karaś-Brzozowska C. 1960. Charakterystyka geomorfologiczna Górnoślq̨skiego Okręgu Przemysłowego. [in:] Klimaszewski M. (ed.) Biul. nr 37. Komitet dla spraw Górnośl. Okręgu Przem. PAN, Warszawa.

Kondracki J. 2002. Geografia regionalna Polski. PWN, Warszawa.

Kotas A. 1982. Zarys budowy geologicznej Górnośląskiego Zagłębia Węglowego. [in:] Różkowski A., Ślósarz J. (eds.) Przew. LIV Zjazdu Pol. Tow. Geol. Wyd. Geol., Warszawa: 45-72.

Lenormand, F., Duguay C.R., Gauthier R. 2002. Development of a historical ice database for the study of climate change in Canada. Hydrological Processes, 16(18): 3707-3722.

Machowski R., Ruman M. 2009: Przebieg zjawisk lodowych zbiornika Czechowice. [in:] Jankowski A.T., Absalon D., Machowski R., Ruman M. (eds.) Przeobrażenia stosunków wodnych $w$ warunkach zmieniającego się środowiska. Uniw. Śl., WNoZ, Pol. Tow. Geogr., Oddz. Katowicki, Regionalny Zarząd Gosp. Wod. w Gliwicach, Sosnowiec: 187-196.

Machowski R., Rzętała M. 2010. Zlodzenie zbiorników wodnych w Kotlinie Dąbrowskiej. [in:] Acta Geogr. Siles., 7: 43-47.

Marszelewski W., Skowron R. 2005. Spatial diversity of the ice cover on the lakes of the European Lowland in the winter season 2003/2004. Limnol. Rev., 5: 155-165.

Marszelewski W., Skowron R. 2006. Ice cover as an indicator of winter air temperature changes: case study of the Polish Lowland lakes. Hydrol. Sc. J., 51 (2): 336-349.

Marszelewski W., Skowron R. 2009. Extreme ice phenomena on the lakes of Northern Poland. Limnol. Rev., 9, 2-3: 81-89.

Pasławski Z. 1982: Zlodzenie jezior w Polsce. Przegl. Geofiz., XXVII, z. 1-2: 79-92.

Pełka-Gościniak J. 2006. Restoring nature in mining areas of the Silesian Upland (Poland). Earth Surface Processes and Landforms, Vol. 31 (13): Ltd.: 1685-1691.

Rzętała M.A. 2003. Procesy brzegowe i osady denne wybranych zbiorników wodnych $w$ warunkach zróżnicowanej antropopresji (na przykładzie Wyżyny Śląskiej i jej obrzeży). Wyd. Uniw. Śl., Katowice.
Rzętała M. 2008. Funkcjonowanie zbiorników wodnych oraz przebieg procesów limnicznych $w$ warunkach zróżnicowanej antropopresji na przykładzie regionu górnośląskiego. Wyd. Uniw. Śl., Katowice.

Rzętała M., 2012. Funkcjonowanie pokrywy lodowej niewielkiego zbiornika wodnego w Czeladzi w latach 2010-2012. Acta Geogr. Siles., nr specj. 2: 71-76.

Rzętała M., Jaguś A., Rzętała M.A. 2009. Zlodzenie zbiorników wodnych w warunkach antropopresji miejsko-przemysłowej (na przykładzie regionu górnośląskiego). [in:] Jankowski A.T., Absalon D., Machowski R., Ruman M., (eds.) Przeobrażenia stosunków wodnych $w$ warunkach zmieniającego się środowiska. Uniw. Śląski, WNoZ, Pol. Tow. Geogr., Oddz. Katowicki, Regionalny Zarząd Gosp. Wod. w Gliwicach, Sosnowiec: 245-254.

Rzętała M., Rzętała M.A. 2009. Zlodzenie niewielkiego zbiornika wodnego (aspekty poznawcze i użytkowe). Kształt. środ. geogr. i ochr. przyr. na obsz. uprzem. i zurb., 40: 171 - 179.

Rzętała M., Solarski M. 2011. Codzienne obserwacje terenowe źródłem identyfikacji nowych form i procesów zlodzenia zbiornika wodnego. $Z$ badań nad wpływem antropopr. na środ., T. 12: 155-161.

Sokołowski J. 1990. Geologia regionalna i złożowa Polski. Wyd. Geol., Warszawa.

Solarski M., Pradela A. 2010. Przebieg zjawisk lodowych w zbiorniku wodnym w niecce osiadania w sezonie zimowym 2008/2009. Kształt. środ. geogr. i ochr. przyr. na obsz. uprzem. i zurb., 42: 70-79.

Solarski M., Pradela A. 2011. Cechy specyficzne zlodzenia zbiorników wodnych na Wyżynie Śląskiej. Z badań nad wpływem antropopr. na środ., T. 12: 69-78.

Solarski M., Pradela A., Rzętała M. 2011. Natural and anthropogenic influences on ice formation on various water bodies of the Silesian Upland (southern Poland) Limnol. Rev., 11, 1: 33-44.

Szczypek T. 1995. Anthropogenic relief in the eastern part of the Silesian Upland. Quaest. Geogr. Special Issue 4: 265270.

Wach J. 1991. Wpływ antropopresji na kształtowanie się rzeźby terenu województwa katowickiego. [in:] Człowiek $i$ jego środowisko $w$ górnośląsko-ostrawskim regionie przemysłowym. Mat. symp. pol.-czes.. Uniw. Śl. WNoZ, Sosnowiec: 115-119.

Żmuda S. 1973. Antropogeniczne przeobrażenia środowiska przyrodniczego konurbacji górnośląskiej. Śl. Inst. Nauk., Katowice. 